\title{
18. MAJOR ELEMENT CHEMISTRY OF THE TERTIARY ROCKS AT SITE 317 AND THE PROBLEM OF THE ORIGIN OF THE NONBIOGENIC FRACTION OF PELAGIC SEDIMENTS
}

\author{
Thomas W. Donnelly and James L. Wallace, Department of Geological Sciences, \\ State University of New York, Binghamton, New York
}

\begin{abstract}
Site 317 belongs to a group of relatively shallow-water, highcarbonate, Central Pacific sites (including also Sites 75 and 167) which have had very limited nonbiogenic sedimentation, evidenced by very low $\mathrm{Al}_{2} \mathrm{O}_{3}$, during the past $30 \mathrm{~m}$.y. The nonbiogenic component of the sediment from the upper part of Site 317 is relatively high in $\mathrm{Ti}$, compared to other Central Pacific sites, suggesting the influence of a local basaltic source. A nearly constant $\mathrm{MgO}$ content probably reflects about a half percent molecular $\mathrm{MgCO}_{3}$ in the skeletal carbonate.
\end{abstract}

\section{INTRODUCTION}

As part of a much larger program of investigation of the major element chemical composition of "typical" deep-sea sediments, 20 samples from the upper 360 meters (middle Eocene and younger) of Site 317 were analyzed. the objectives of the larger program are to determined the origin of the nonbiogenic fraction of pelagic sediments and the secondary behavior of $\mathrm{Mg}$, $\mathrm{Na}, \mathrm{K}$, and $\mathrm{Fe}$. Site 317 proved to have remarkably pure $\mathrm{CaCO}_{3}$ sediments in the upper 360 meters; only Site 167 (unpublished data) has sediment of comparable purity. Consequently, the results from Site 317 are largely of interest in a negative sense, although considered in relation to results from other Central Pacific sites (Figure 1, $42,70,73,75,166$, and 167 , unpublished data,: these results provide an interesting insight into some of the chemical problems of pelagic sedimentation.

\section{ANALYTICAL TECHNIQUES}

Our laboratory uses techniques (colorimetric and atomic absorption on borate fusions) described briefly by Donnelly and Nalli (1973), with the addition of a chloride determination (mercuric nitrate titration) to correct for pore-water $\mathrm{Mg}, \mathrm{Na}$, and $\mathrm{K}$. For Site 317 we have used pore-water $\mathrm{Mg}$ and $\mathrm{K}$ data from Gieskes (this volume). For nearly pure $\mathrm{CaCO}_{3}$ sediments we have had to use more concentrated solutions for the Al determination and a longer $(5 \mathrm{~cm})$ tube for the Ti determination. Our accuracy (using USGS rock standards as blind unknowns) has been as follows, expressed as average absolute percent of the amount present: $\mathrm{SiO}_{2}, 3.9 \%, \mathrm{TiO}_{2}$, $4.1 \% ; \mathrm{Al}_{2} \mathrm{O}_{3}, 1.4 \% ; \mathrm{Fe}_{2} \mathrm{O}_{3}{ }^{*}, 2.1 \% ; \mathrm{MnO}, 27 \% ; \mathrm{MgO}$, $4.9 \% ; \mathrm{CaO}, 3.5 \% ; \mathrm{Na}_{2} \mathrm{O}, 2.4 \% ; \mathrm{K}_{2} \mathrm{O}, 3.5 \% ; \mathrm{P}_{2} \mathrm{O}_{5}, 10 \%$. The relatively large errors for $\mathrm{Mn}$ and $\mathrm{P}$ reflect the small amounts of these elements present in the USGS rock standards. It is very difficult to estimate the errors for the present determinations, but the relative coherence of $\mathrm{Al}_{2} \mathrm{O}_{3}$ and $\mathrm{TiO}_{2}$ (Figure 2) will give some idea of the error for these two elements.

\section{RESULTS}

Table 1 shows that the 20 analyzed samples are nearly pure $\mathrm{CaCO}_{3}$. Major elements other than $\mathrm{Ca}$ occur in very minor amounts, and, except for $\mathrm{Si}$ and $\mathrm{Mg}$, can be considered to be trace elements. Aluminum occurs here in amounts as low as $1500 \mathrm{ppm}$ and titanium as low as $60 \mathrm{ppm}$; only Site 167 shows comparably low values for these elements ( $\mathrm{Al}$ as low as $30 \mathrm{ppm}$; $\mathrm{Ti}$ as low as 12 ppm; unpublished data).

The very low $\mathrm{Si}$ reflects a very limited contribution of siliceous organisms; all other Central Pacific sites investigated $(42,70,73,166,167)$ have much higher $\mathrm{Si}$; Site 75 has about twice as high a content of $\mathrm{Si}$ as Site 317. Manganese and phosphorus (only four analyses) are low but not remarkable, except that only Site 167 shows so little manganese among the other Central Pacific sites. Virtually all the sodium and potassium in these sediments is accounted for by pore water.

Magnesium is a nearly constant minor element throughout the section. In other sites with a high clay content the $\mathrm{Mg} / \mathrm{Al}$ ratio tends to reflect a terrigenous provenance. At certain opaline sites (unpublished data), $\mathrm{Mg}$ is evidently adsorbed on opaline materials in major amounts. Site 317 , in contrast, shows the clearest evidence to date for the near constancy (Figure 3) of small $\mathrm{Mg}$ contribution in the carbonate phase as $\mathrm{MgCO}_{3}$. This fraction seems to vary from around $0.65 \%$ in shallow samples to $0.45 \%$ in deeper samples. The smaller content in deeper samples could result from recrystallization of the carbonate to produce purer secondary $\mathrm{CaCO}_{3}$, but the amount of $\mathrm{Mg}$ thereby released into the pore water would amount to about a third of the amount present and should be reflected in the porewater $\mathrm{Mg}$. Because the pore-water $\mathrm{Mg}$ is fairly constant with depth in the Tertiary part of Site 317 (Gieskes, this volume), the alternative explanation that the average $\mathrm{MgCO}_{3}$ content of the calcareous debris has increased by about nearly a half since the Eocene should be considered. 
T. W. DONNELLY, J. L. WALLACE

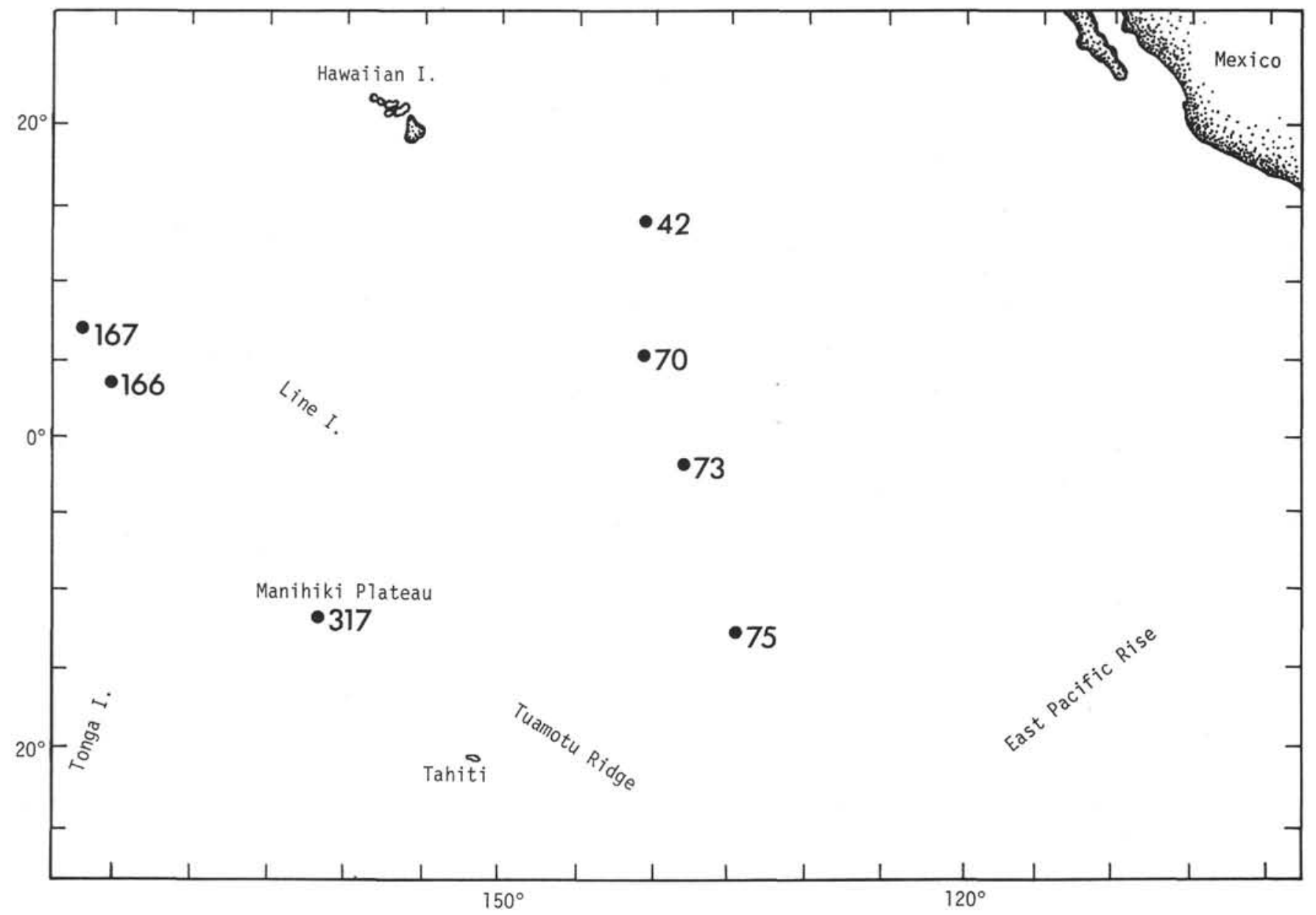

Figure 1. Index map showing location of Site 317 and other Central Pacific sites.

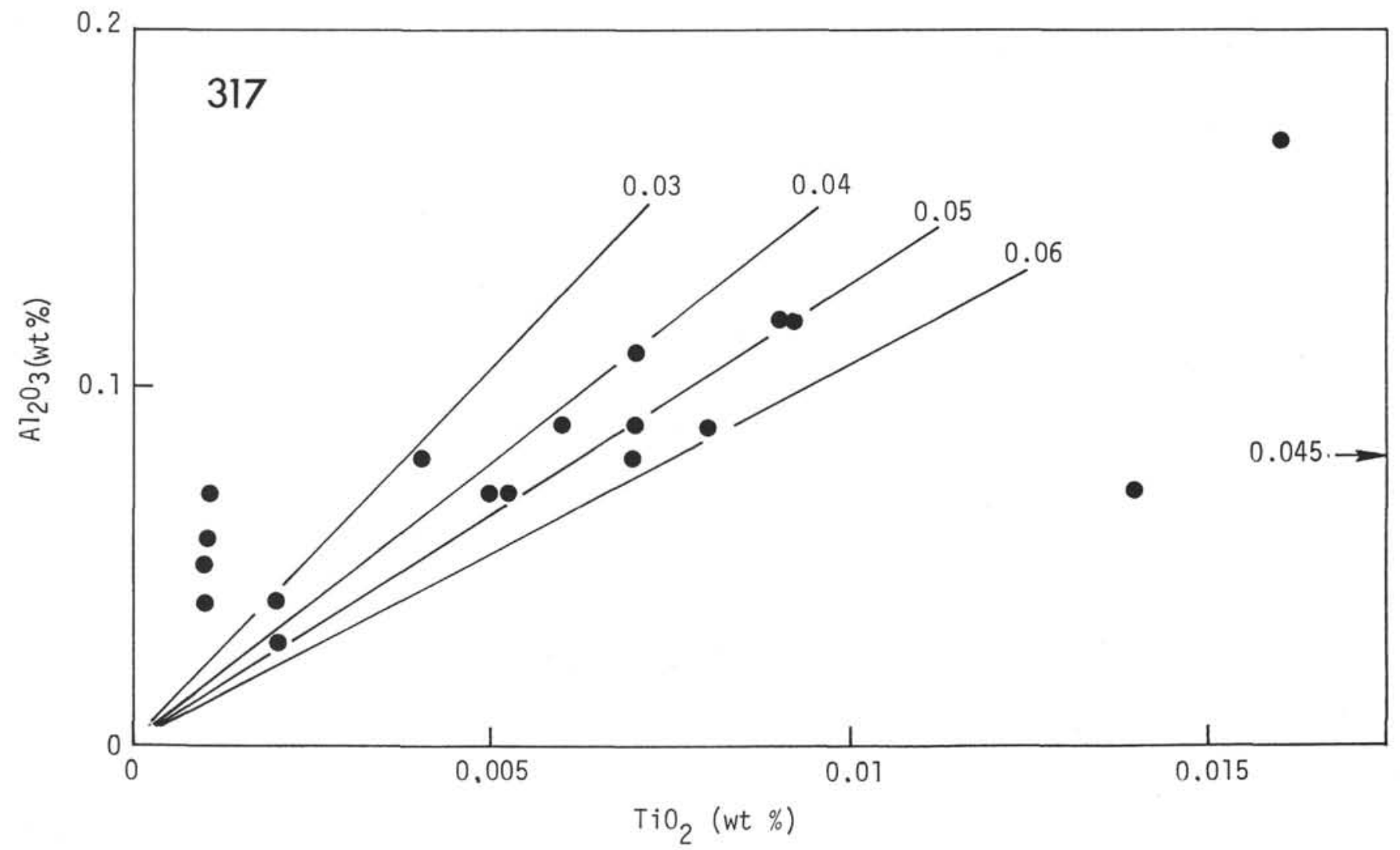

Figure 2. Graph showing $\mathrm{Al}_{2} \mathrm{O}_{3}$ versus $\mathrm{TiO}_{2}$ for Site 317. Italicized numbers adjacent to slanting lines show Ti/Al(atomic) ratio of these lines. 
TABLE 1

Chemical Composition of Samples From Site 317

\begin{tabular}{|c|c|c|c|c|c|c|c|c|c|c|c|c|}
\hline $\begin{array}{l}\text { Sample } \\
\text { (Interval } \\
\text { in } \mathrm{cm} \text { ) }\end{array}$ & $\begin{array}{l}\text { Depth } \\
\text { (m) }\end{array}$ & $\mathrm{SiO}_{2}$ & $\mathrm{TiO}_{2}$ & $\mathrm{Al}_{2} \mathrm{O}_{3}$ & $\mathrm{Fe}_{2} \mathrm{O}_{3}$ & $\mathrm{MnO}$ & $\mathrm{MgO}^{\mathrm{a}}$ & $\mathrm{CaO}$ & $\mathrm{Na}_{2} \mathrm{O}^{\mathrm{a}}$ & $\mathrm{K}_{2} \mathrm{O}^{\mathrm{a}}$ & $\mathrm{P}_{2} \mathrm{O}_{5}$ & $\mathrm{Cl}$ \\
\hline $1-6,118$ & 9 & 0.54 & 0.009 & 0.12 & 0.1 & nd & 0.27 & 55.5 & nd & 0.01 & nd & 1.31 \\
\hline $2-5,73$ & 13 & 0.32 & 0.008 & 0.09 & $\operatorname{tr}$ & 0.03 & 0.26 & 54.8 & .04 & 0 & 0.08 & 1.19 \\
\hline $4-5,81$ & 32 & 0.34 & 0.007 & 0.09 & $\operatorname{tr}$ & nd & 0.29 & 55.8 & nd & 0 & nd & 1.30 \\
\hline $6-5,114$ & 52 & 0.29 & 0.007 & 0.08 & nil & nd & 0.29 & 55.7 & nd & 0 & nd & 1.25 \\
\hline $8-5,113$ & 71 & 0.22 & 0.002 & 0.04 & nil & nd & 0.21 & 56.4 & nd & 0 & nd & 1.10 \\
\hline $10-4,88$ & 88 & 0.58 & 0.009 & 0.12 & nil & nd & 0.23 & 56.6 & nd & 0 & nd & 1.32 \\
\hline $13-4,45$ & 116 & 0.81 & 0.006 & 0.09 & tr & nd & 0.21 & 56.6 & nd & 0.01 & nd & 1.16 \\
\hline $16-5,78$ & 146 & 0.65 & 0.001 & 0.07 & nil & nd & 0.25 & 56.6 & nd & 0.01 & nd & 1.16 \\
\hline $18-5,118$ & 166 & 1.42 & 0.007 & 0.11 & tr & 0.04 & 0.27 & 57.6 & .04 & 0 & nd & 0.98 \\
\hline $20-5,91$ & 184 & 0.75 & 0.001 & 0.05 & nil & nd & 0.22 & 55.2 & nd & 0 & nd & 1.01 \\
\hline $23-5,89$ & 213 & 0.45 & 0.001 & 0.04 & nil & nd & 0.25 & 57.0 & nd & 0 & nd & 0.94 \\
\hline $23-5,97$ & 213 & 0.63 & 0.014 & 0.07 & nil & nd & 0.17 & 57.0 & nd & 0 & nd & 0.94 \\
\hline $25-5,95$ & 232 & 1.12 & 0.005 & 0.07 & nil & 0.03 & 0.20 & 59.2 & .04 & 0 & 0.05 & 0.69 \\
\hline $27-5,102$ & 251 & 0.94 & 0.004 & 0.08 & nil & nd & 0.22 & 53.5 & nd & 0 & nd & 0.74 \\
\hline $29-5,123$ & 270 & 0.37 & 0.045 & 0.08 & nil & nd & 0.17 & 55.6 & nd & 0.01 & nd & 0.69 \\
\hline $31-5,111$ & 289 & 0.28 & 0.002 & 0.03 & nil & nd & 0.15 & 54.4 & nd & 0 & nd & 0.82 \\
\hline $33-5,98$ & 308 & 0.22 & 0.001 & 0.06 & nil & nd & 0.27 & 57.6 & nd & 0 & nd & 0.93 \\
\hline $35-5,104$ & 327 & nd & nd & nd & nd & nd & 0.17 & 57.8 & nd & 0 & nd & 0.68 \\
\hline $37-2,82$ & 341 & 0.48 & 0.016 & 0.17 & 1.88 & nd & 0.17 & 58.4 & nd & 0.01 & nd & 0.48 \\
\hline $39-5,102$ & 365 & 0.35 & 0.005 & 0.07 & nil & 0.06 & 0.19 & 55.2 & 0 & 0 & 0.06 & 0.74 \\
\hline
\end{tabular}

Note: Analyst was James Wallace; $\mathrm{nd}=$ not determined; $\mathrm{Fe}_{2} \mathrm{O}_{3}{ }^{*}=$ total iron as ferric oxide.

${ }^{a}$ Solid phase values, assuming $\mathrm{Mg} / \mathrm{Cl}=0.0639$ (Gieskes, this volume), $\mathrm{K} / \mathrm{Cl}=0.0021$ (ibid), $\mathrm{Na} / \mathrm{Cl}=0.5612$.

The behavior of aluminum, which is taken as the best index of nonbiogenic sedimentation, is very interesting at the Central Pacific sites that have been examined. The origin of the nonbiogenic fraction is not clear, but we can consider four sources: (1) local, intrabasinal vulcanism (dominantly basaltic), (2) water-borne continental debris, traveling out into the Central Basin largely in surface currents, (3) water-borne continental debris entering the Central Pacific in the bottom water, or (4) wind-borne continental debris. To these choices we must add the secondary effect of redistribution of debris within the basin by bottom currents. The examination of Site 317, and a comparison with other Central Pacific sites, does not provide a definitive answer to the main question, but it does supply some constraints on the larger problem.

Table 2 shows estimates for the total $\mathrm{Al}_{2} \mathrm{O}_{3}$ that has accumulated in each of several sites in the past 30 m.y. The accuracy of the estimate depends further on whether the sampling is representative and whether the 30 m.y. level can be identified in the sediment column. For the latter, we have used the time scale of Berggren (1972), in which the 30 m.y. level is taken as the boundary of foraminiferal Zones P20 and P21; just below the boundary between nannoplankton Zones NP24 and NP23; and at the top of the $T$. tuberosa radiolarian zone. The overall results show a very large spread of values, and the possible errors in their estimate are considered to be relatively minor.

There is no clear relationship between the $\mathrm{Al}_{2} \mathrm{O}_{3}$ accumulation and the position of the site. One site with a high accumulation (166) in this group is one of two of the westernmost sites of the group and might have been expected to show a low value reflecting great distance from North and South American sources. There is some realtionship between $\mathrm{CaCO}_{3}$ content and accumulation of $\mathrm{Al}_{2} \mathrm{O}_{3}$, suggesting that water depth at time of deposition might be of major importance in the accumulation of nonbiogenic material. The cause of the depth difference is not known: either the bulk of nonbiogenic sediment travels in a nepheloid layer and is not deposited on topographically high areas that accumulate clacareous sediment, or bottom currents continually winnow the very fine material from these high areas, leaving coarser skeletal debris behind.

The coherence between $\mathrm{Ti}$ and $\mathrm{Al}$ provides an important clue as to the ultimate origin (and, hence, possibly of transport mechanisms) of the nonbiogenic debris. At four sites (Figures 4-7) with higher values of $\mathrm{Al} \mathrm{ac}$ cumulation $(42,70,73,166)$ the $\mathrm{Ti} / \mathrm{Al}$ ratios are indistinguishable from values for average shales or related source materials (Table 3). Site 167 (Figure 8) shows a very low $\mathrm{Ti} / \mathrm{Al}$ ratio. Because the values of these elements are also very low, there is a suspicion of analytical uncertainty that cannot be ruled out (these samples were the only ones treated with EDTA to enhance $\mathrm{Ti}$ and $\mathrm{Al}$ ). Unless the EDTA treatment selectively removed $\mathrm{Ti}$, the low ratio is probably real. Such a low ratio is unique in our experience; very possibly it reflects dominantly wind-carried debris, in which the shape factor favors the transport of muscovitic clay minerals, which have a very low $\mathrm{Ti} / \mathrm{Al}$ ratio (Table 3 ). Site 317 (Figure 2) shows on the other hand, a relatively high $\mathrm{Ti} / \mathrm{Al}$ ratio. The most straightforward explanation for this is that a local basaltic source is involved. Site 75 (Figure 9) shows a problematic scatter in the $\mathrm{Ti} / \mathrm{Al}$ ratio; either there is a variable mixture of source material or there has been secondary redistribution of $\mathrm{Ti}$.

The major points that emerge from a chemical examination of these Central Pacific sites is that sites with a relatively high accumulation of $\mathrm{Al}_{2} \mathrm{O}_{3}$ show, in the 


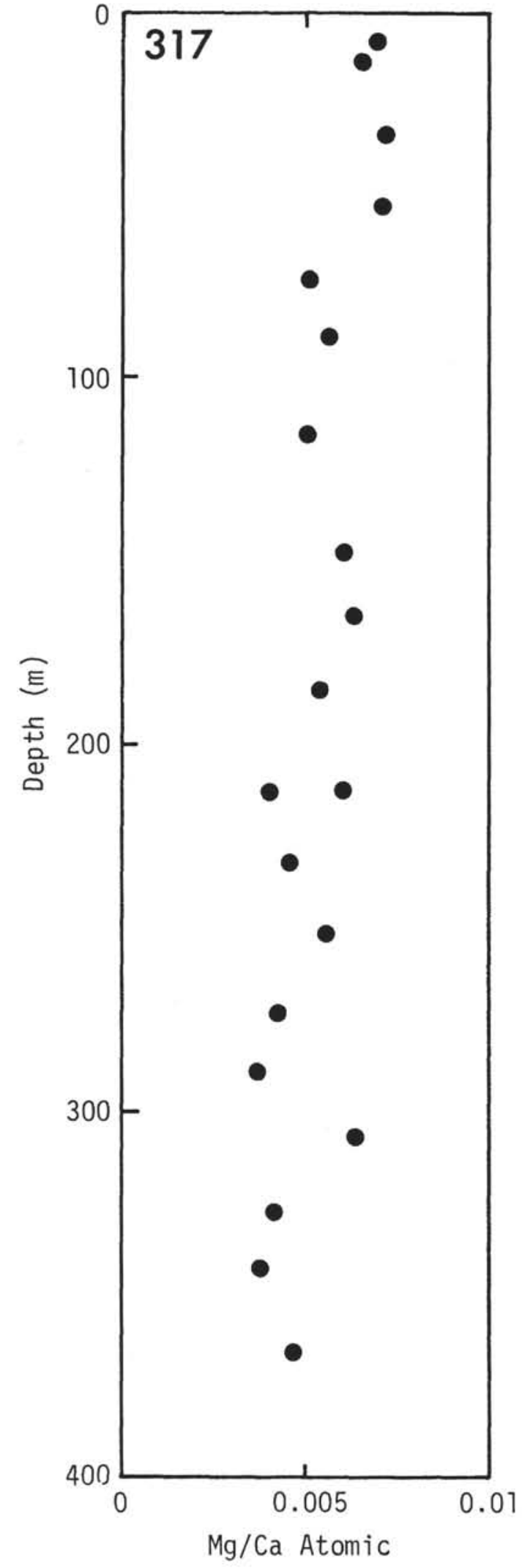

Figure 3. Graph showing $\mathrm{Mg} / \mathrm{Ca}$ (atomic) versus depth for Site 317. The Mg has been corrected for pore-water $M g$.

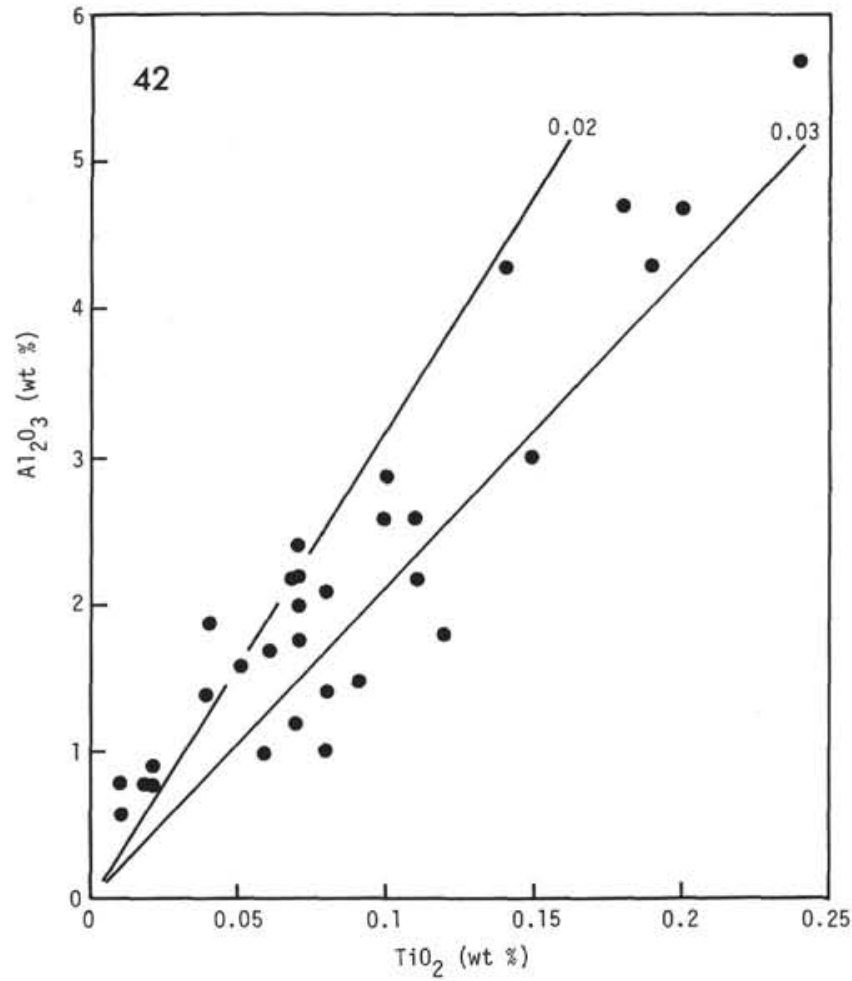

Figure 4. Graph showing $\mathrm{Al}_{2} \mathrm{O}_{3}$ versus $\mathrm{TiO}_{2}$ for Site 42 . Explanation as for Figure 2.

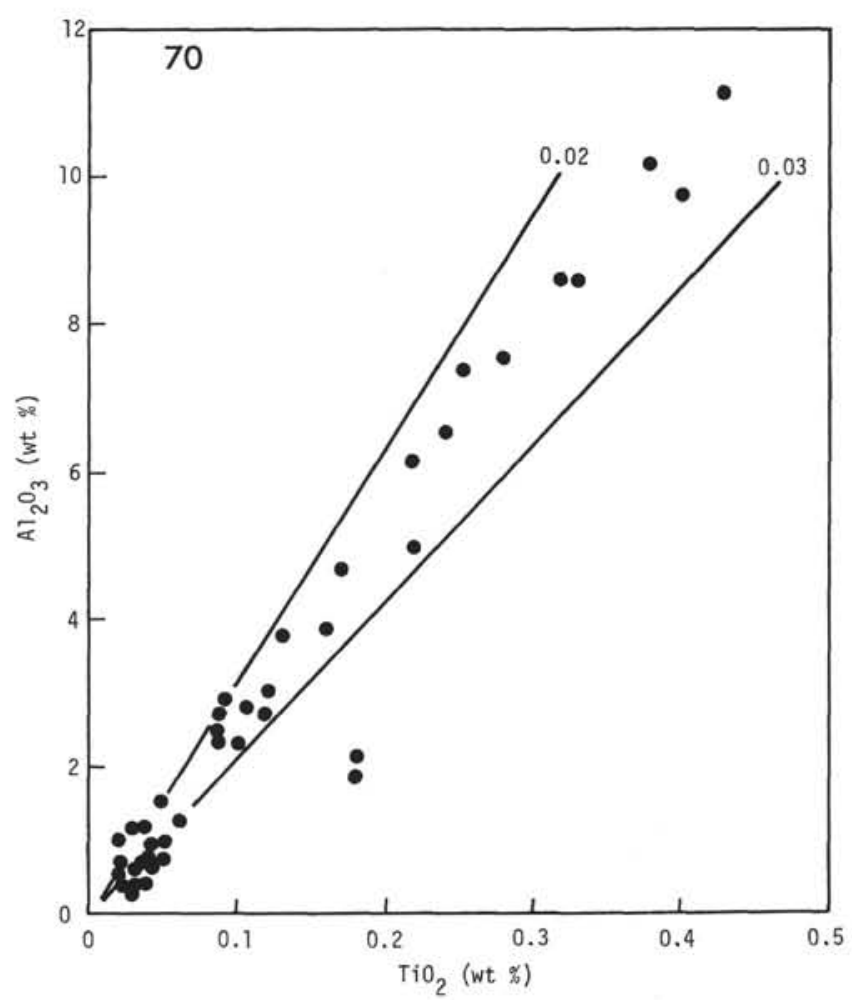

Figure 5. Graph showing $\mathrm{Al}_{2} \mathrm{O}_{3}$ versus $\mathrm{TiO}_{2}$ for Site 70 . Explanation as for Figure 2 . 
TABLE 2

Accumulation of $\mathrm{Al}_{2} \mathrm{O}_{3}$ in 30 m.y. at Six Central Pacific Sites

\begin{tabular}{rcccccc}
\hline Site & $\begin{array}{c}\text { Depth } \\
(\mathrm{m})\end{array}$ & Lat & Long & $\mathrm{CaCO}_{3}{ }^{\mathrm{a}}$ & $\mathrm{CaCO}_{3}{ }^{\mathrm{b}}$ & $\mathrm{Al}_{2} \mathrm{O}_{3}$ \\
\hline 70 & 5059 & $6^{\circ} 20^{\prime} \mathrm{N}$ & $140^{\circ} 22^{\prime} \mathrm{W}$ & 53 & 70 & 330 \\
73 & 4387 & $1^{\circ} 55^{\prime} \mathrm{S}$ & $137^{\circ} 28^{\prime} \mathrm{W}$ & 72 & 67 & 119 \\
75 & 4181 & $12^{\circ} 31^{\prime} \mathrm{S}$ & $134^{\circ} 16^{\prime} \mathrm{W}$ & 79 & 85 & 18 \\
166 & 4962 & $3^{\circ} 46^{\prime} \mathrm{N}$ & $175^{\circ} 5^{\prime} \mathrm{W}$ & 7 & 6 & 236 \\
167 & 3176 & $7^{\circ} 4^{\prime} \mathrm{N}$ & $176^{\circ} 50^{\prime} \mathrm{W}$ & 95 & 94 & 23 \\
317 & 2598 & $11^{\circ} 0^{\prime} \mathrm{S}$ & $162^{\circ} 16^{\prime} \mathrm{W}$ & 100 & - & $16^{\mathrm{c}}$ \\
\hline
\end{tabular}

${ }^{\text {a}}$ Estimated from chemical data, assuming all $\mathrm{Ca}$ as $\mathrm{CaCO}_{3}$.

${ }^{b}$ From Winterer, Ewing, et al., 1973, Appendix II, and Tracey, Sutton, et at., 1971, Appendix III.

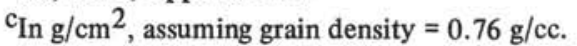

TABLE 3

Representative Ti/Al (Atomic) Ratios

\begin{tabular}{lcl}
\hline \multicolumn{1}{c}{ Material } & $\begin{array}{c}\text { Ti/Al } \\
\text { (atomic) }\end{array}$ & \multicolumn{1}{c}{ Reference } \\
\hline $\begin{array}{l}\text { Clay-Gulf of Paria } \\
\text { "Clay," Russia; all } \\
\text { geological ages }\end{array}$ & 0.032 & Hirst, 1962 \\
$\begin{array}{l}\text { Average clay, from } \\
\text { Clarke }\end{array}$ & 0.033 & Vinogradov and Ronov, 1956 \\
$\begin{array}{l}\text { Mississippi } \\
\begin{array}{l}\text { Littleton Fm., } \\
\text { metapelite }\end{array}\end{array}$ & 0.027 & $\begin{array}{l}\text { Pettijohn, 1957, Table 61 } \\
\text { Pettijohn, 1957, Table 61 }\end{array}$ \\
$\begin{array}{l}\text { Average shale } \\
\text { "Typical" illite }\end{array}$ & 0.036 & $\begin{array}{l}\text { Shaw, 1956 } \\
\text { S.R. Taylor, unpublished }\end{array}$ \\
$\begin{array}{l}\text { Low-K tholeiite } \\
\text { Tholeiite }\end{array}$ & 0.056 & $\begin{array}{l}\text { Weaver and Pollard, 1973, } \\
\text { Table III }\end{array}$ \\
\hline
\end{tabular}

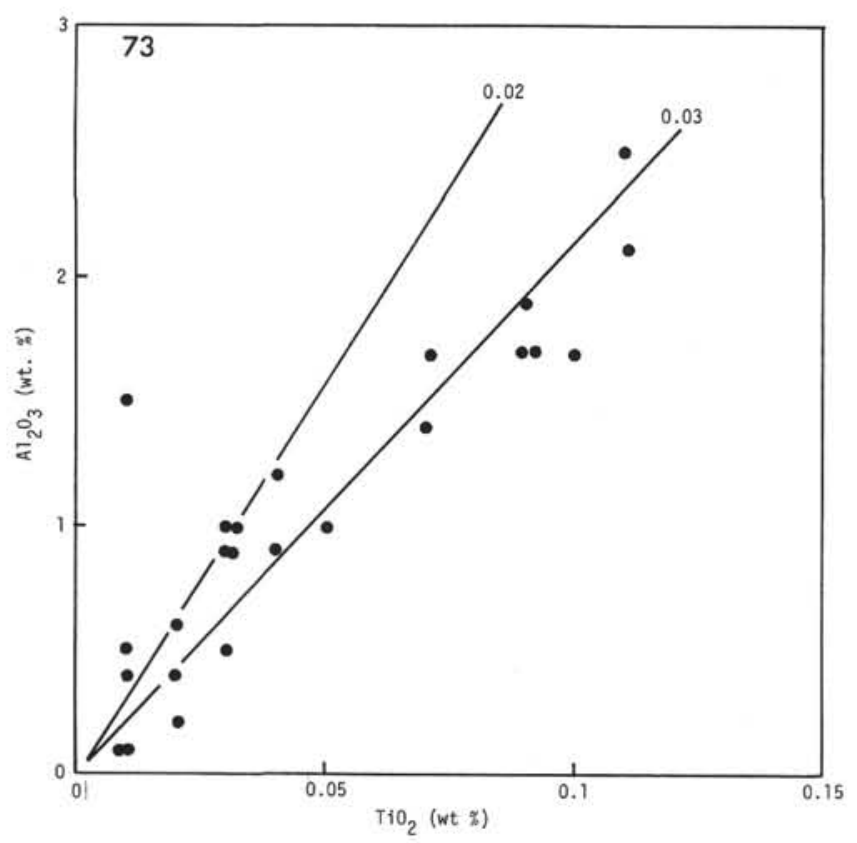

Figure 6. Graph showing $\mathrm{Al}_{2} \mathrm{O}_{3}$ versus $\mathrm{TiO}_{2}$ for Site 73. Explanation as for Figure 2.

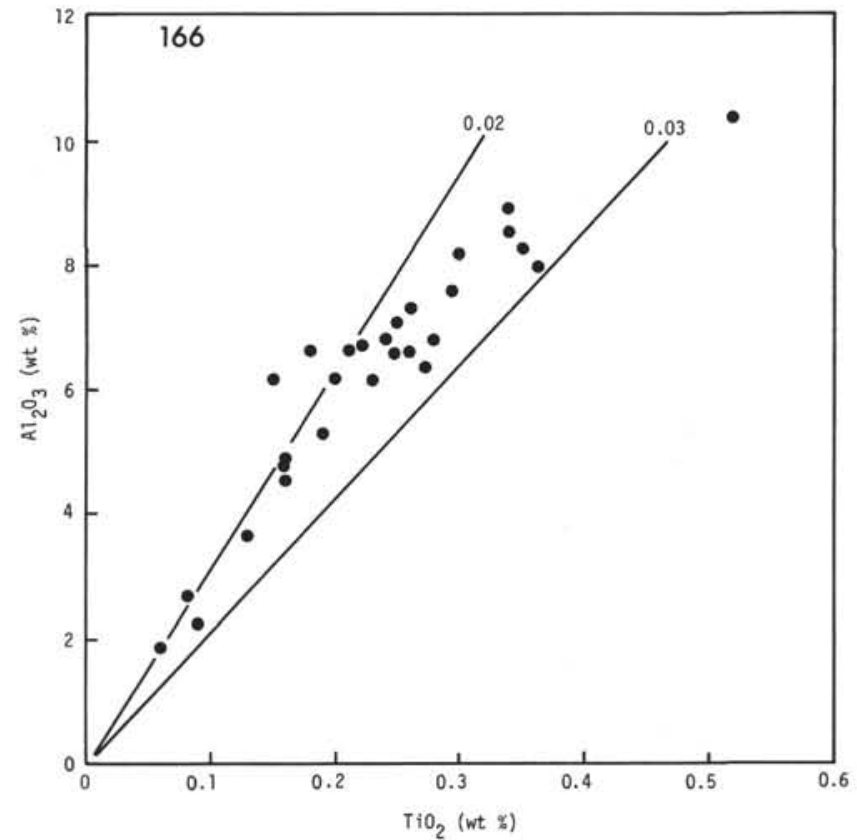

Figure 7. Graph showing $\mathrm{Al}_{2} \mathrm{O}_{3}$ versus $\mathrm{TiO}_{2}$ for Site 166. Explanation as for Figure 2.

$\mathrm{Ti} / \mathrm{Al}$ ratio a terrigenous origin. Because the $\mathrm{Ti} / \mathrm{Al}$ ratio might be expected to be lower if a shape factor favored mica in eolian transport, we might further speculate that such transport carried relatively little of the Central Pacific debris. The correlation of higher accumulation rates with topographically lower areas suggests the importance of bottom currents and/or the nepheloid layer. A question not resolved in the present investigation is whether the continental debris enters the Pacific in a bottom current from the Antarctic (and the Atlantic) or whether there is an important contribution from the equatorial current, which is then redistributed by bottom currents. The argument might be resolved if there were deep water sites in the south Central Pacific (which would show lower $\mathrm{Al}_{2} \mathrm{O}_{3}$ accumulation than sites north of the equator). The absence of such sites, and the scarcity of any southern central Pacific sites, leaves this problem presently unresolved. 


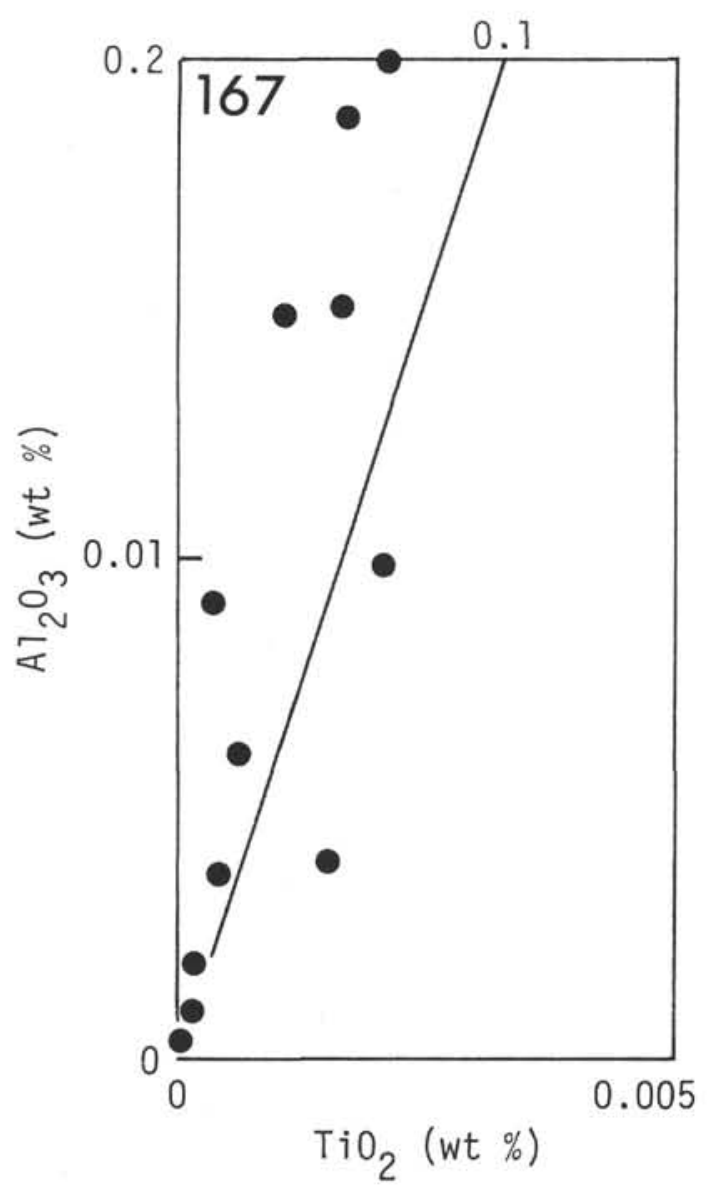

Figure 8. Graph showing $\mathrm{Al}_{2} \mathrm{O}_{3}$ versus $\mathrm{TiO}_{2}$ for

Site 167. Explanation as for Figure 2.

\section{ACKNOWLEDGMENTS}

We gratefully acknowledge the staff of the West Coast Repository, DSDP, for sampling several of these sites for us. Samples were supplied by the National Science Foundation. Unpublished chemical data from S.R. Taylor is also acknowledged. Joris Gieskes kindly provided pore-water chemical data for Site 317 in advance of publication. This work was supported by Grant A-043210 from the National Science Foundation.

\section{REFERENCES}

Berggren, W.A., 1972. A Cenozoic time scale-some implication for regional geology and paleobiogeography: Lethaia, v. 5 , p. $195-512$.

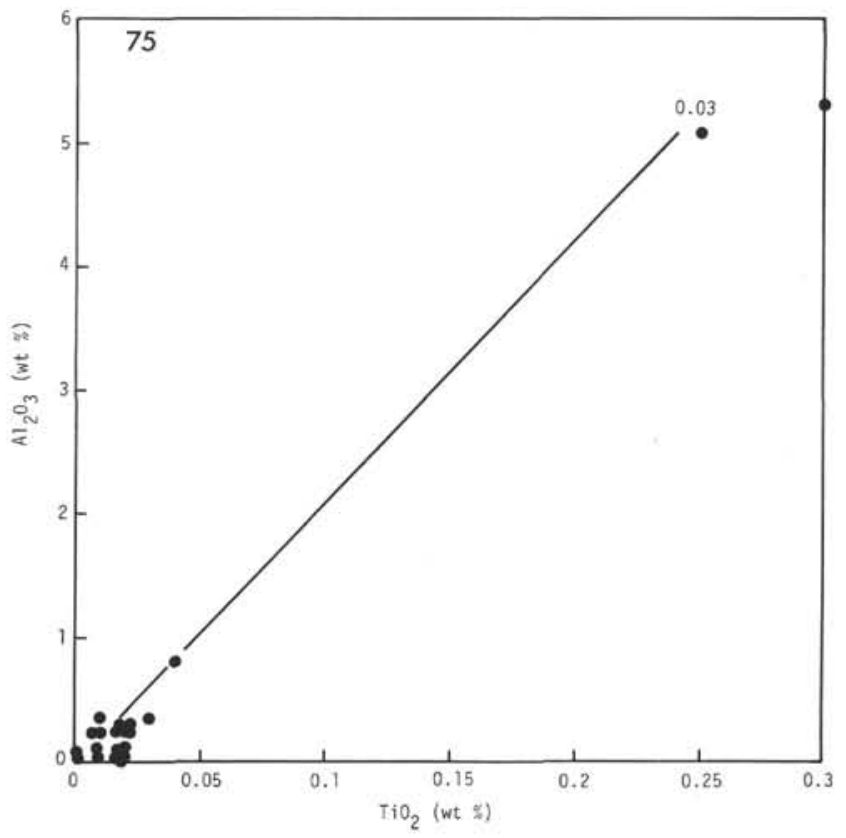

Figure 9. Graph showing $\mathrm{Al}_{2} \mathrm{O}_{3}$ versus $\mathrm{TiO}_{2}$ for Site 75. Explanation as for Figure 2.

Donnelly, T.W. and Nalli, G., 1973. Mineralogy and chemistry of Caribbean sediments. In Edgar, N.T., Saunders, J.B., et al., Initial Reports of the Deep Sea Drilling Project, Volume 15: Washington (U.S. Government Printing Office), p. 929-961.

Hirst, D.M., 1962. The geochemistry of modern sediments from the Gulf of Paria-I. The relationship between the mineralogy and the distribution of the major elements: Geochim. Cosmochim. Acta, v. 26, p. 309-334.

Pettijohn, F.J., 1957. Sedimentary rocks. New York (Harper \& Bros.).

Shaw, D.M., 1956. Geochemistry of pelitic rocks. Part III: Major elements and general geochemistry: Geol. Soc. Am. Bull., v. 67, p.919-934.

Tracey, J.I., Jr., Sutton, G.H., et al., 1971. Initial Reports of the Deep Sea Drilling Project, Volume 7: Washington (U.S. Government Printing Office).

Vinogradov. A.P. and Ronov, A:B., 1956. Composition of the sedimentary rocks of the Russian platform in relation to the history of its tectonic movements: Geochemistry, v. , p. 533-559.

Weaver, C.E. and Pollard, L.D., 1973. The chemistry of clay minerals: Amsterdam (Elsevier).

Winterer, E.L., Ewing, J.I., et al., 1973. Initial Reports of the Deep Sea Drilling Project, Volume 17: Washington (U.S. Government Printing Office). 